\title{
Jamie Frueh (ed). 2020. Pedagogical Journeys through World Politics. London: Palgrave Macmillan.
}

\author{
Michael P. A. Murphy", University of Ottawa
}

In recent decades, scholars of International Relations have paid increasing attention to the pedagogical development of the discipline. The latest landmark contribution to this discussion is the collection Pedagogical Journeys through World Politics, edited by Jamie Frueh, which brings together 23 authors from a variety of institutions to discuss their teaching and learning experiences. Employing a unique autobiographical form, reading the collected essays is an intensely personal experience. Whether we are confronting urgency through the lively prose of Naeem Inayatullah's polemic against teaching, or following Eric Leonard's unexpected journey to a professorship (and the important lessons about teaching to be gained along the way), the unique style of this volume offers a kaleidoscope of teaching experiences.

The way that the authors capture the ongoing debate on the value of lecturing validates the editorial decision for Pedagogical Journeys to favour freedom over consistency. Patrick Thaddeus Jackson notes the reproduction of lecturing practices as if by osmosis-the lesson gleaned from his own classroom experience was that "I needed to lecture, students would take notes, then l'd administer an exam or two and grade them" (43). There are strong arguments against the traditional model of lecturing with a PowerPoint-in Inayatullah's words, "God forbid and common sense prohibit" (20) - but that practice is also defended, so long as it is employed "to model analysis and demonstrating methods for sorting nuances that deserve attention from those most likely to be smokescreen or noise" (Frueh 6) or as part of a larger toolbox of effective knowledge performance (Dunn). While there is no defense of the unapologetic sage on the stage as impassioned as the lecture's critics, there is an argument that the lecture is sometimes the tool that makes sense. Given the salience of this debate in the contemporary academy, this volume is a worthy contribution on those grounds alone.

Another way that the volume draws strength from its diversity of contributions is by acknowledging the different pedagogical and institutional circumstances from which the different contributors speak. In addition to the typical academic biographical statement, Frueh includes a description of the authors' current institution (e.g., "small private liberal arts college"), their typical classroom setting (e.g., "seminars and large classes" or "mid-sized classes, mostly upper division"), their typical pedagogical approach (e.g., "lecture, Socratic, active learning"), as well as their disciplinary identity. These profiles provide important context to the reader, both to give a sense of the wide variety of institutional perspectives assembled in the volume, and at an individual level to foreground the context in which particular interventions should be understood.

Frueh's introduction intertwines a reflection on the disciplinary pedagogical developments since 2000 while also calling for further attention to the specificity of International Relations pedagogy.

\footnotetext{
*Biography :

Michael PA Murphy is SSHRC doctoral fellow in International Relations and Political Theory at the University of Ottawa, and author of Quantum Social Theory for Critical International Relations Theorists: Quantizing Critique (Palgrave Macmillan, 2021). He serves as an elected school board trustee, Editorial Assistant at Security Dialogue and program co-chair for ISA's Active Learning in International Affairs Section. He has published two dozen peer-reviewed articles, appearing in International Relations, Contemporary Security Policy, the Cambridge Review of International Affairs, Critical Studies on Security, the Journal of Political Science Education, and elsewhere. His work can be found at: http://bit.ly/37NJMkZ

Biographie :

Michael PA Murphy est titulaire d'une bourse de doctorat du CRSH en relations internationales et en théorie politique à I'Université d'Ottawa, et auteur de Quantum Social Theory for Critical International Relations Theorists : Quantizing Critique (Palgrave Macmillan, 2021). Il est membre élu du conseil d'administration scolaire, assistant de rédaction pour la revue Security Dialogue et co-président de programme pour la section d'apprentissage actif en affaires internationales de l'ISA (International Studies Association). II a publié deux douzaines d'articles évalués par des pairs, parus dans International Relations, Contemporary Security Policy, Cambridge Review of International Affairs, Critical Studies on Security, le Journal of Political Science Education, et ailleurs. Ses travaux peuvent être consultés à l'adresse suivante : http://bit.ly/37NJMkZ
} 
Echoing the introduction to The New International Studies Classroom (Lantis et al 2000), Frueh concurs that there is a natural link between the subject matter of International Relations and active forms of learning. "Global politics courses," Frueh remarks, "provide opportunities for emerging agents to practice wrestling with the kinds of complexities they will confront in an increasingly globalized world, and drawing attention to global political issues unfolding in real time provides evidence of the practical value of our courses" (5). The personal reflections shared throughout the book are-beyond a fascinating montage of reflections from great teachers-opportunities for further reflection on the place of the classroom as a place of transformation. Formal, disciplinary knowledge is enlivened through discussion, abstract concepts are applied to real world politics, and teachers continually confront new perspectives through exchange with their students.

Pedagogical Journeys is an important contribution to the growing community of teaching and learning in International Relations. While it is commonly remarked that all teaching is personal to some extent, the novel autobiographical style of this work makes the personal connection between readers and writers through this volume all the more intense. Not only does it merit a place on the pedagogue's bookshelf as one of the most significant volumes on teaching and learning since The New International Studies Classroom, but also for its enjoyable and lively prose.

\section{References}

Lantis, Jeffrey S., Lynn M. Kuzma, and John Boehner. 2000. Introduction to The New International Studies Classroom: Active Teaching, Active Learning. Boulder, CO: Lynne Reinner. 